\title{
Tetradecylthioacetic acid inhibits proliferation of human SW620 colon cancer cells - gene expression profiling implies endoplasmic reticulum stress
}

Anne G Lundemo ${ }^{1 \dagger}$, Caroline HH Pettersen ${ }^{1 \dagger}$, Kjetil Berge ${ }^{2 \dagger}$, Rolf K Berge ${ }^{2}$ and Svanhild A Schønberg ${ }^{1 *}$

\begin{abstract}
Background: Previous reports have shown an antiproliferative effect of the synthetic, 3-thia fatty acid tetradecylthioacetic acid (TTA) on different cancer cells in vitro and in vivo. The mechanisms behind the observed effects are poorly understood. We therefore wanted to explore the molecular mechanisms involved in TTA-induced growth inhibition of the human colon cancer cell line SW620 by gene expression profiling.

Methods: An antiproliferative effect of TTA on SW620 cells in vitro was displayed in real time using the XCELLigence System (Roche). Affymetrix gene expression profiling was performed to elucidate the molecular mechanisms behind the antiproliferative effect of TTA. Changes in gene expression were verified at protein level by western blotting.

Results: TTA reduced SW620 cell growth, measured as baseline cell index, by 35\% and 55\% after $48 \mathrm{~h}$ and $72 \mathrm{~h}$, respectively. We show for the first time that TTA induces an endoplasmic reticulum (ER) stress response in cancer cells. Gene expression analysis revealed changes related to ER stress and unfolded protein response (UPR). This was verified at protein level by phosphorylation of eukaryote translation initiation factor 2 alpha (elF2 $\alpha$ ) and downstream upregulation of activating transcription factor 4 (ATF4). Transcripts for positive and negative cell cycle regulators were down- and up-regulated, respectively. This, together with a down-regulation of Cyclin D1 at protein level, indicates inhibition of cell cycle progression. TTA also affected transcripts involved in calcium homeostasis. Moreover, mRNA and protein level of the ER stress inducible C/EBP-homologous protein (CHOP), Tribbles homolog 3 (Drosophila) (TRIB3) and CCAAT/enhancer binding protein beta (C/EBP $\beta$ ) were enhanced, and the C/EBP $\beta$ LIP/LAP ratio was significantly increased. These results indicate prolonged ER stress and a possible link to induction of cell death.
\end{abstract}

Conclusion: We find that TTA-induced growth inhibition of SW620 cells seems to be mediated through induction of ER stress and activation of the UPR pathway.

Keywords: Cell cycle, Colon cancer, Docosahexaenoic acid, Endoplasmic reticulum stress, Gene expression analysis, Phosphorylated elF2a, Tetradecylthioacetic acid, Thia fatty acids, Unfolded protein response

\section{Background}

Colon cancer is one of the most common incident cancers across Europe [1]. There is an urgent need for finding novel, alternative or supplementary cancer treatments. Polyunsaturated fatty acids (PUFAs) are able

\footnotetext{
* Correspondence: svanhild.schonberg@ntnu.no

+ Contributed equally

'Norwegian University of Science and Technology, Faculty of Medicine, Department of Laboratory Medicine, Children's and Women's Health, PO Box 8905, N-7491 Trondheim, Norway

Full list of author information is available at the end of the article
}

to inhibit growth of both colon and several other types of cancer cells in vitro and in vivo ([2-5] and reviewed in [6-8]). During the last two decades, chemical modified fatty acid (FA) analogs have been produced in an attempt to achieve FAs having increased metabolic stability and more selective and targeted effects (reviewed in [9]). Among these is the bioactive, saturated 3-thia FA tetradecylthioacetic acid (TTA). TTA has been shown to have both a cardioprotective effect, as well as an antiproliferative effect on cancer cells (reviewed in

\section{() Biomed Central}


[10]). TTA has been found to inhibit growth of glioma [11,12], leukemia [13-16] and colon cancer cell lines $[11,17]$ in vitro and in vivo, and hepatoma [18] and breast cancer cells [19] in vitro. TTA seems to be more potent in reducing cell growth compared with the omega-3 (n-3) PUFAs eicosapentaenoic acid (EPA) and docosahexaenoic acid (DHA) [20]. A diet containing TTA has also resulted in increased vascularisation of colon cancer xenografts in mice [17] and improved the survival of mice having leukemia xenografts $[11,14]$. TTA food supplementation seems to be generally well tolerated by healthy persons $[15,21]$, and TTA therefore may have a potential in cancer treatment alone or in combination with other therapies.

The structure of TTA is equal to the saturated palmitic acid (PA), except that TTA has a sulphur atom inserted at the third position in the carbon chain [19]. The sulphur atom makes TTA resistant to mitochondrial $\beta$-oxidation and probably contributes substantial to its biological effects (reviewed in [10]). TTA is capable of reducing the growth of cancer cells that are not growth inhibited by PA $[17,20,22]$. TTA is degraded relatively slowly to various dicarboxylic acids via $\omega$-oxidation and sulphur oxidation in the endoplasmic reticulum (ER) and subsequent $\beta$-oxidation in the peroxisomes. Except from blocked mitochondrial $\beta$-oxidation, the chemical properties and metabolism of TTA resembles those of normal FAs. TTA is activated by binding to coenzyme A and incorporated into various lipids, especially phospholipids (reviewed in $[10,23]$ ).

Before any recommendations regarding use of TTA in cancer treatment can be given, it's important to elucidate the molecular mechanisms underlying the growth inhibitory effect of TTA. In some, but not all, cancer cells, TTA inhibits cancer cell growth via increased lipid peroxidation and oxidative stress [12], or partly via activation of peroxisome proliferator activated receptor gamma [22]. Also, TTA has been shown to induce apoptosis in several glioma $[12,13]$ and leukemia cell lines $[13,14]$. Induction of apoptosis seems to be related to effects on mitochondria. TTA can induce a decrease in mitochondrial membrane potential $[13,24]$ and lead to release of cytochrome $\mathrm{C}$ (cyt $\mathrm{C}$ ) and a reduction in mitochondrial glutathione, the latter indicating a selective modulation of the mitochondrial redox equilibrium [13]. Most of the biological effects of TTA assumed to be implicated in mediating the inhibitory effect of TTA on cancer cells do not seem to be specific for TTA, since they also are assumed to be involved in the growth inhibitory effect of other FAs like n-3 PUFAs [25-27].

We have previously shown that TTA inhibits the growth of SW620 human colon cancer cells in vitro and in vivo [17]. SW620 cell growth is also inhibited by $\mathrm{n}-3$ PUFAs $[2,4]$. By using gene expression analysis, we found that DHA induces extensive changes in the expression of transcripts involved in biological pathways like ER stress and unfolded protein response (UPR), protein degradation, $\mathrm{Ca}^{2+}$ homeostasis, cell cycle progression and apoptosis [28]. Others have found that PA also can induce ER stress in human [29] and rat cancer cells [30].

The main functions of ER are protein synthesis and folding, lipid synthesis and maintenance of $\mathrm{Ca}^{2+}$ homeostasis. Disruption of these processes causes accumulation of misfolded proteins in ER lumen, leading to ER stress and activation of the cellular stress response UPR. The purpose of UPR is to restore cell homeostasis and promote cell survival, but during prolonged ER stress, apoptosis may be activated. During ER stress, one of the three ER stress sensors; eukaryotic translation initiation factor 2 alpha (eIF2 $\alpha$ ) kinase 3 (EIF2AK3/PERK) is known to phosphorylate eIF2 $\alpha$, thereby attenuating global protein synthesis to reduce the protein load of ER. Reduced synthesis of e.g. cyclin D1 promotes cell cycle arrest, creating time to cope with the stress. However, translation of certain mRNAs is allowed, like mRNAs for activating transcription factor 4 (ATF4) and its downstream target C/EBP-homologous protein (CHOP) $[31,32]$. CHOP, which is also regulated by X-box binding protein 1 (XBP-1) (reviewed in [33]), promotes apoptosis by down-regulating anti-apoptotic factors like B-cell lymphoma 2 (Bcl-2) [34] and up-regulating proapoptotic factors like the Bcl-2-interacting protein Bim [35].

During ER stress XBP-1 also activates the transcription factor CCAAT/enhancer binding protein beta $(\mathrm{C} /$ EBP $\beta$ ) [36], which participates in regulation of differentiation, cell growth, cell survival and apoptosis $[37,38]$. Human C/EBP $\beta$ is mainly expressed as two 46 and 42 $\mathrm{kDa}$ liver enriched activator protein isoforms (LAP and LAP*) and a $20 \mathrm{kDa}$ liver enriched inhibitor protein isoform (LIP) [39], which are synthesized from different AUG start codons within the C/EBP $\beta$ mRNA [40]. Since LIP lacks a transcription activation domain [41] and suppresses the transactivation by LAP, the LIP/LAP ratio influences on the extent of $\mathrm{C} / \mathrm{EBP} \beta$-activated transcription [40].

LIP has been shown to decrease during early ER stress, and increase during prolonged ER stress, causing an increase in the LIP/LAP ratio [42]. Increased LIP seems to be essential for CHOP-induced apoptosis, since heterodimerization of LIP with CHOP promotes nuclear translocation of $\mathrm{CHOP}$ and pro-apoptotic gene regulation by $\mathrm{CHOP}$ [43]. In addition, $\mathrm{CHOP-C/EBP} \beta$ [44] and CHOP-ATF4 [45] heterodimeres up-regulate the pro-apoptotic pseudo-kinase Tribbles homolog 3 (Drosophila) (TRIB3), which can promote apoptosis by inhibiting the anti-apoptotic kinase Akt [46] and the 
transcription factor nuclear factor kappa-light-chainenhancer of activated B cells (NF- $\kappa$ B) [47]. CHOP- and TRIB3-promoted cell death might be accompanied by the ER stress-induced caspase 4 (CASP4) and calpains $[32,48,49]$.

In this report we have used Affymetrix gene expression analysis to search for possible molecular mechanisms underlying the growth inhibitory effect of TTA on SW620 cells in vitro. The results indicate that TTA reduces SW620 cell growth through activation of ER stress and UPR, by a similar mechanism as observed after treatment with DHA [28].

\section{Results}

\section{TTA reduces growth of SW620 cells}

In accordance with previous results [17], we verified a growth inhibitory effect of TTA $(75 \mu \mathrm{M})$ on SW620 colon cancer cells by cell counting (data not shown) and by measuring the growth real time by using the xCELLigence System (Roche) (Figure 1A). The SW620 growth curve, which is presented as baseline cell index, showed that TTA $(75 \mu \mathrm{M})$ significantly reduced the baseline cell index by $35 \%$ and $55 \%$ after $48 \mathrm{~h}$ and $72 \mathrm{~h}$, respectively, compared to the control (Figure 1B).

\section{TTA induces extensive changes at mRNA level indicating ER stress and UPR}

In an attempt to unravel the mechanisms underlying the growth-inhibiting effect of TTA, SW620 cells were cultivated in the absence or presence of $75 \mu \mathrm{M}$ TTA for 24 $\mathrm{h}$, followed by gene expression profiling. Differentially expressed transcripts are presented and listed by full and short names in Table 1 and Additional file 1.

After incubation with TTA, the transcription level of several genes involved in ER stress and UPR were affected. The ER stress sensors inositol-requiring enzyme 1 (IRE1) and activating transcription factor 6 (ATF6), and downstream targets of these, like XBP-1, were up-regulated (Table 1). However, most changes in the ER stress signaling pathway were found downstream of PERK. Phosphorylation of eIF2 $\alpha$ by PERK is a hallmark of ER stress (reviewed in [31]). After TTA treatment, phosphorylated eIF2 $\alpha$ (eIF $2 \alpha-\mathrm{P}$ ) was found significantly increased after $6 \mathrm{~h}$ and $24 \mathrm{~h}$ (Figure 2A).

Phosphorylation of eIF $2 \alpha$ induces transcription of ATF4 and its downstream targets, like ATF3, CHOP, growth arrest and DNA-damage-inducible 34 (GADD34), TRIB3 [50,51] and heme oxygenase 1 (HMOX1) [52]. All these transcripts were up-regulated upon TTA treatment (Table 1). Moreover, the protein levels of ATF4, CHOP (Figure 2A) and TRIB3 (Figure 2B) were also increased. ATF4 is known to induce genes involved in amino acid synthesis, and several transcripts involved in amino acid synthesis and transport were also up-regulated (Table 1 and Additional file 1).

When UPR is activated, cells try to up-regulate the folding capacity e.g. through up-regulation of chaperones and heat shock proteins (Hsps) [31]. Transcripts of the folding machinery were found to be up-regulated in the SW620 cells after incubation with TTA. These include prefoldin 2 (PFDN2), DnaJ (HSP40) homolog, subfamily B, member 2 (DNAJB2), DNAJB14, DnaJ
A)

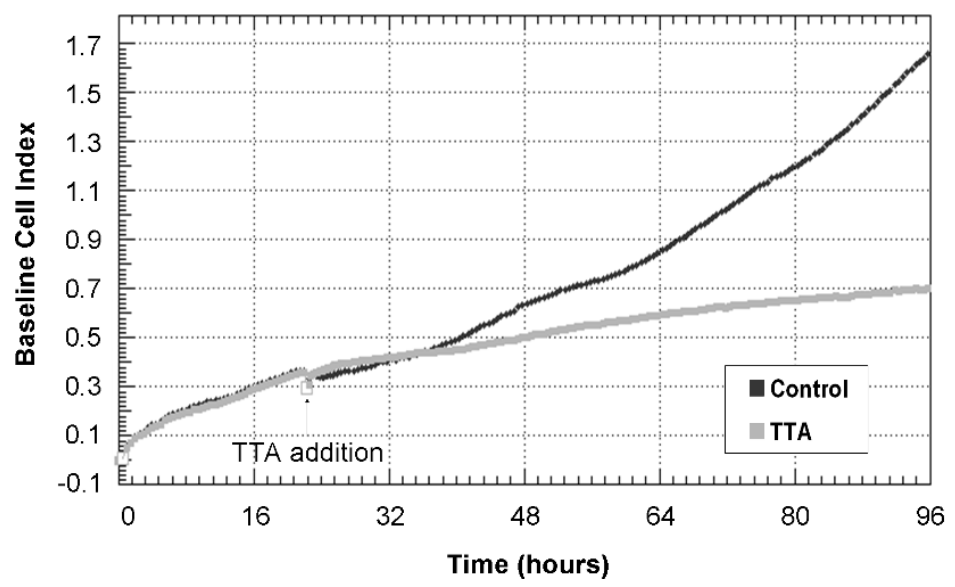

B)

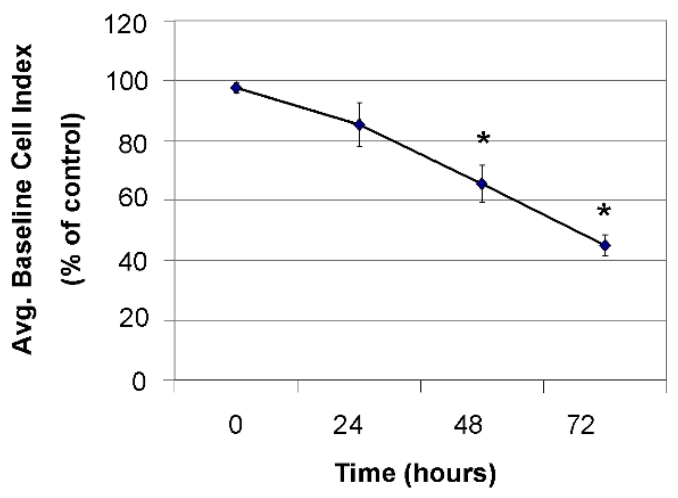

Figure 1 Real time monitoring of TTA-induced growth inhibition of SW620 cells. SW620 colon cancer cells were seeded in 16 well Eplates. After $\sim 24 \mathrm{~h}, \mathrm{TTA}(75 \mu \mathrm{M})$ or $\mathrm{NaOH}$ (control) were added. Cell growth was monitored using the xCELLigence RTCA DP Instrument (Roche). (A) SW620 cell growth presented as baseline cell index from one representative experiment. (B) Average baseline cell index ( \pm SD) of TTA-treated cells, presented as percent of control, at indicated time points. Mean was calculated from at least two duplicate measurements in four independent experiments. ${ }^{*}$ Significantly different from control (one-tailed Student's t-test, $\mathrm{P}<0.05$ ). 
Table 1 Gene expression results

\begin{tabular}{|c|c|c|c|c|}
\hline \multirow[t]{2}{*}{ Gene Symbol } & \multirow[t]{2}{*}{$\begin{array}{l}\text { Affymetrix } \\
\text { ID }\end{array}$} & \multirow[t]{2}{*}{$\begin{array}{l}\text { Refseq NCBI } \\
\text { ID }\end{array}$} & \multirow[t]{2}{*}{ Transcript name } & \multirow{2}{*}{$\begin{array}{r}\begin{array}{c}\text { SW620 } \\
\text { Fold } \\
\text { Chang }\end{array} \\
24 \mathrm{~h}\end{array}$} \\
\hline & & & & \\
\hline \multicolumn{5}{|c|}{ ER stress and unfolded protein response } \\
\hline ATF3 & 202672_s_at & $\begin{array}{l}\text { NM_001030287 } \\
\text { NM_001040619 } \\
\text { NM_001674 } \\
\text { NM_004024 }\end{array}$ & Activating transcription factor 3 & 3.5 \\
\hline ATF4 & 200779_at & $\begin{array}{l}\text { NM_001675 } \\
\text { NM_182810 }\end{array}$ & Activating transcription factor 4 & 1.7 \\
\hline ATF6 & $\begin{array}{l}\text { 217550_at } \\
\text { 231927_at } \\
\text { 203952_at }\end{array}$ & NM_007348 & Activating transcription factor 6 & $\begin{array}{l}1.5 \\
1.3 \\
1.2 \\
\end{array}$ \\
\hline CEBPB & 212501_at & NM_005194 & CCAAT/enhancer binding protein (C/EBP), beta & 3.2 \\
\hline CHOP/DDIT3 & 209383_at & $\begin{array}{l}\text { NM_001130101 } \\
\text { NM_001130102 } \\
\text { NM_004083 } \\
\text { NM_005693 }\end{array}$ & DNA-damage-inducible transcript 3 & 2.7 \\
\hline GADD34 & $\begin{array}{l}\text { 37028_at } \\
\text { 202014_at }\end{array}$ & NM_014330 & Growth arrest and DNA-damage-inducible 34 & $\begin{array}{l}2.0 \\
2.0\end{array}$ \\
\hline IRE1/ERN1 & 235745_at & NM_001433 & Inositol-requiring enzyme 1/Endoplasmic reticulum to nucleus signaling 1 & 1.7 \\
\hline NRF2/NFE2L2 & 201146_at & $\begin{array}{l}\text { NM_001145412 } \\
\text { NM_001145413 } \\
\text { NM_006164 }\end{array}$ & Nuclear factor (erythroid-derived 2)-like 2 & 1.3 \\
\hline TRIB3 & $\begin{array}{l}\text { 1555788_a_at } \\
\text { 218145_at }\end{array}$ & NM_021158 & Tribbles homolog 3 (Drosophila) & $\begin{array}{l}5.1 \\
4.9\end{array}$ \\
\hline XBP1 & $\begin{array}{l}\text { 242021_at } \\
\text { 200670_at }\end{array}$ & $\begin{array}{l}\text { NM_001079539 } \\
\text { NM_005080 }\end{array}$ & X-box binding protein 1 & $\begin{array}{l}1.2 \\
1.6\end{array}$ \\
\hline \multicolumn{5}{|c|}{ Chaperones/Protein folding/Unfolded protein response/Protein degradation/Amino acid synthesis } \\
\hline ASNS & 205047_s_at & $\begin{array}{l}\text { NM_001673 } \\
\text { NM_133436 } \\
\text { NM_183356 }\end{array}$ & Asparagine synthetase & 4.8 \\
\hline CREB3L2 & 212345_s_at & NM_194071 & CAMP responsive element binding protein 3-like 2 & 1.4 \\
\hline CREB3L3 & 234361_at & NM_032607 & CAMP responsive element binding protein 3-like 3 & 3.0 \\
\hline DNAJB2 & 202500_at & $\begin{array}{l}\text { NM_001039550 } \\
\text { NM_006736 }\end{array}$ & DnaJ (Hsp40) homolog, subfamily B, member B2 & 1.3 \\
\hline DNAJB14 & 222850_s_at & NM_001031723 & DnaJ (Hsp40) homolog, subfamily B, member B14 & 1.2 \\
\hline DNAJC24 & 242562_at & NM_181706 & DnaJ (Hsp40) homolog, subfamily C, member 24 & 1.4 \\
\hline EDEM1 & 203279_at & NM_014674 & ER degradation enhancer, mannosidase alpha-like 1 & 1.3 \\
\hline EDEM3 & 220342_x_at & NM_025191 & ER degradation enhancer, mannosidase alpha-like 3 & 1.2 \\
\hline ERO1LB & 231944_at & NM_019891 & ERO1-like beta (S. cerevisiae) & 1.3 \\
\hline HMOX1/HSP32 & 203665_at & NM_002133 & Heme oxygenase (decycling) 1 & 1.6 \\
\hline HSPA13 & $\begin{array}{l}\text { 202557_at } \\
\text { 202558_s_at }\end{array}$ & NM_006948 & Heat shock 70kDa protein 13 & $\begin{array}{l}1.4 \\
1.7 \\
\end{array}$ \\
\hline PDIA2 & 206691_s_at & NM_006849 & Protein disulfide isomerase family $\mathrm{A}$, member 2 & 1.2 \\
\hline PFDN2 & 218336_at & NM_012394 & Prefoldin 2 & 1.4 \\
\hline PSMB1 & 214289_at & NM_002793 & Proteasome subunit, beta type, 1 & 1.3 \\
\hline SQSTM1 & $\begin{array}{l}\text { 201471_s_at } \\
\text { 213112_s_at } \\
\text { 239004_at } \\
\text { 244804_at }\end{array}$ & $\begin{array}{l}\text { NM_001142298 } \\
\text { NM_001142299 } \\
\text { NM_003900 }\end{array}$ & Sequestosome 1 & $\begin{array}{l}2.1 \\
3.1 \\
1.3 \\
2.1\end{array}$ \\
\hline UBE2B & 239163_at & NM_003337 & Ubiquitin-conjugating enzyme E2B (RAD6 homolog) & 1.5 \\
\hline SEC61A2 & $\begin{array}{l}\text { 219499_at } \\
\text { 228747_at }\end{array}$ & $\begin{array}{l}\text { NM_001142627 } \\
\text { NM_001142628 } \\
\text { NM_018144 }\end{array}$ & Sec61 alpha 2 subunit (S. cerevisiae) & $\begin{array}{l}1.3 \\
1.2\end{array}$ \\
\hline
\end{tabular}


Table 1 Gene expression results (Continued)

\begin{tabular}{|c|c|c|c|c|}
\hline SEC61B & 244700_at & NM_006808 & Sec61 beta subunit & 1.6 \\
\hline SEC63 & $\begin{array}{l}\text { 201914_s_at } \\
\text { 201915_s_at } \\
\text { 201916_s_at }\end{array}$ & NM_007214 & SEC63 homolog (S. cerevisiae) & $\begin{array}{l}1.3 \\
1.2 \\
1.3\end{array}$ \\
\hline \multicolumn{5}{|c|}{$\mathrm{Ca}^{+}$homeostasis, signaling and transport } \\
\hline ATP2B4/PMCA4 & $\begin{array}{l}\text { 205410_s_at } \\
\text { 212135_s_at } \\
\text { 212136_at }\end{array}$ & $\begin{array}{l}\text { NM_001001396 } \\
\text { NM_001684 }\end{array}$ & ATPase, $\mathrm{Ca}^{2+}$ transporting, plasma membrane 4 & $\begin{array}{l}1.5 \\
2.7 \\
5.4\end{array}$ \\
\hline CAPN1 & 232012_at & NM_005186 & Calpain 1, (mu/l) large subunit & 1.4 \\
\hline CAPN2 & $\begin{array}{l}\text { 208683_at } \\
\text { 214888_at }\end{array}$ & $\begin{array}{l}\text { NM_001146068 } \\
\text { NM_001748 }\end{array}$ & Calpain 2, large subunit & $\begin{array}{l}1.4 \\
1.8\end{array}$ \\
\hline CAPN5 & 205166_at & NM_004055 & Calpain 5 & 1.4 \\
\hline HERPUD1 & 217168_s_at & $\begin{array}{l}\text { NM_001010989 } \\
\text { NM_001010990 } \\
\text { NM_014685 }\end{array}$ & $\begin{array}{l}\text { Homocysteine-inducible, endoplasmic reticulum stress-inducible, ubiquitin-like } \\
\text { domain member } 1\end{array}$ & 1.9 \\
\hline ITPR1 & 244090_at & - & Inositol 1,4,5-triphosphate receptor, type 1 & 1.3 \\
\hline ITPR3 & $\begin{array}{l}\text { 201187_s_at } \\
\text { 201188_s_at } \\
\text { 201189_s_at }\end{array}$ & NM_002224 & Inositol 1,4,5-triphosphate receptor, type 3 & $\begin{array}{l}1.3 \\
1.5 \\
1.5\end{array}$ \\
\hline PLCD3 & $\begin{array}{l}\text { 234971_x_at } \\
1552476 \_s \_a t\end{array}$ & NM_133373 & Phospholipase C, delta 3 & $\begin{array}{l}1.3 \\
1.3\end{array}$ \\
\hline S100A10 & $\begin{array}{l}\text { 200872_at } \\
\text { 238909_at }\end{array}$ & NM_002966 & S100 calcium binding protein A10 & $\begin{array}{l}1.2 \\
2.4\end{array}$ \\
\hline S100P & 204351_at & NM_005980 & S100 calcium binding protein $\mathrm{P}$ & 4.9 \\
\hline STC2 & $\begin{array}{l}\text { 203438_at } \\
\text { 203439_s_at }\end{array}$ & NM_003714 & Stanniocalcin 2 & $\begin{array}{l}2.1 \\
2.7 \\
\end{array}$ \\
\hline \multicolumn{5}{|l|}{$\begin{array}{l}\text { Cell cycle/ } \\
\text { Apoptosis }\end{array}$} \\
\hline ATF5 & $\begin{array}{l}204998 \text { s_at } \\
\text { 204999_s_at }\end{array}$ & NM_012068 & Activating transcription factor 5 & $\begin{array}{l}1.5 \\
1.7\end{array}$ \\
\hline AURKA & 208080_at & $\begin{array}{l}\text { NM_003600 } \\
\text { NM_198433 } \\
\text { NM_198434 } \\
\text { NM_198435 } \\
\text { NM_198436 } \\
\text { NM_198437 }\end{array}$ & Aurora kinase A & -1.3 \\
\hline $\mathrm{BIRC5}$ & $\begin{array}{l}\text { 202094_at } \\
\text { 202095_s_at } \\
\text { 210334_x_at }\end{array}$ & $\begin{array}{l}\text { NM_001012270 } \\
\text { NM_001012271 } \\
\text { NM_001168 }\end{array}$ & Baculoviral IAP repeat-containing 5/Survivin & $\begin{array}{l}-1.7 \\
-1.3 \\
-1.3\end{array}$ \\
\hline CASP4 & 213596_at & $\begin{array}{l}\text { NM_001225 } \\
\text { NM_033306 }\end{array}$ & Caspase 4 & 1.4 \\
\hline CCNA2 & $\begin{array}{l}\text { 203418_at } \\
\text { 213226_at }\end{array}$ & NM_001237 & Cyclin A2 & $\begin{array}{l}-1.2 \\
-1.2\end{array}$ \\
\hline CCND3 & 201700_at & $\begin{array}{l}\text { NM_001136017 } \\
\text { NM_001136125 } \\
\text { NM_001136126 } \\
\text { NM_001760 }\end{array}$ & Cyclin D3 & -2.0 \\
\hline CCNE1 & 213523_at & $\begin{array}{l}\text { NM_001238 } \\
\text { NM_057182 }\end{array}$ & Cyclin E1 & -1.3 \\
\hline CCNE2 & $\begin{array}{l}\text { 205034_at } \\
\text { 211814_s_at }\end{array}$ & NM_057749 & Cyclin E2 & $\begin{array}{l}-2.9 \\
-3.1 \\
\end{array}$ \\
\hline CCNF & 204827_s_at & NM_001761 & Cyclin F & -1.2 \\
\hline CDC2/CDK1 & 203214_x_at & $\begin{array}{l}\text { NM_001130829 } \\
\text { NM_001786 } \\
\text { NM_033379 }\end{array}$ & Cell division cycle 2, G1 to S and G2 to M & -1.2 \\
\hline CDK2 & $\begin{array}{l}\text { 204252_at } \\
\text { 211804_s_at }\end{array}$ & $\begin{array}{l}\text { NM_001798 } \\
\text { NM_052827 }\end{array}$ & Cyclin-dependent kinase 2 & $\begin{array}{l}-1.3 \\
-1.4\end{array}$ \\
\hline
\end{tabular}


Table 1 Gene expression results (Continued)

\begin{tabular}{|c|c|c|c|c|}
\hline CDK4 & 202246_s_at & NM_000075 & Cyclin-dependent kinase 4 & -1.4 \\
\hline CDK5 & 204247_s_at & $\begin{array}{l}\text { NM_001164410 } \\
\text { NM_004935 }\end{array}$ & Cyclin-dependent kinase 5 & -1.5 \\
\hline CDK6 & $\begin{array}{l}\text { 224847_at } \\
224848 \text { at } \\
224851 \text { at } \\
243000 \text { at }\end{array}$ & $\begin{array}{l}\text { NM_001145306 } \\
\text { NM_001259 }\end{array}$ & Cyclin-dependent kinase 6 & $\begin{array}{l}-1.4 \\
-1.5 \\
-1.3 \\
-1.3\end{array}$ \\
\hline CDKN2A & 211156_at & $\begin{array}{l}\text { NM_000077 } \\
\text { NM_058195 } \\
\text { NM_058197 }\end{array}$ & Cyclin-dependent kinase inhibitor 2A (melanoma, p16, inhibits CDK4) & 1.3 \\
\hline CDKN2B & $\begin{array}{l}\text { 207530_s_at } \\
\text { 236313_at }\end{array}$ & $\begin{array}{l}\text { NM_004936 } \\
\text { NM_078487 }\end{array}$ & Cyclin-dependent kinase inhibitor 2B (p15, inhibits CDK4) & $\begin{array}{l}1.5 \\
2.0\end{array}$ \\
\hline CDKN2D & 210240_s_at & $\begin{array}{l}\text { NM_001800 } \\
\text { NM_079421 }\end{array}$ & Cyclin-dependent kinase inhibitor 2D ( $p 19$, inhibits CDK4) & 1.2 \\
\hline CUL1 & 238509_at & NM_003592 & Cullin 1 & 1.4 \\
\hline KLF4 & $\begin{array}{l}\text { 220266_s_at } \\
\text { 221841_s_at }\end{array}$ & NM_004235 & Kruppel-like factor 4 (gut) & $\begin{array}{l}1.9 \\
2.4\end{array}$ \\
\hline PDCD4 & $\begin{array}{l}\text { 202731_at } \\
\text { 212593_s_at }\end{array}$ & $\begin{array}{l}\text { NM_014456 } \\
\text { NM_145341 }\end{array}$ & Programmed cell death 4 (neoplastic transformation inhibitor) & $\begin{array}{l}1.3 \\
1.3 \\
\end{array}$ \\
\hline PDCD6 & $\begin{array}{l}\text { 222152_at } \\
\text { 222380_s_at }\end{array}$ & NM_013232 & Programmed cell death 6 & $\begin{array}{l}1.3 \\
1.3 \\
\end{array}$ \\
\hline SFN & $\begin{array}{l}\text { 33322_i_at } \\
\text { 33323_r_at } \\
209260 \text { at }\end{array}$ & NM_006142 & Stratifin & $\begin{array}{l}1.6 \\
1.7 \\
1.6\end{array}$ \\
\hline
\end{tabular}

Significantly differentially expressed transcripts in SW620 treated with TAA $(75 \mu \mathrm{M})$ for $24 \mathrm{~h}$ as determined by Affymetrix microarray analysis $(\mathrm{P}<0.05)$.

(Hsp40) homolog, subfamily C, member 24 (DNAJC24), heat shock protein 13 (HSPA13), HSP32 (HMOX1) and hypoxia up-regulated 1 (HYOU1) (Table 1 and Additional file 1). Protein disulfide isomerase family A, member 2 (PDIA2) and ERO1-like beta (ERO1LB), which are known to catalyze protein folding $[31,53]$, were also upregulated (Table 1). However, some DnaJ (Hsp40) homolog subfamily members and Hsps were also found to be down-regulated (Additional file 1).

During ER stress, improperly folded proteins are transferred to ER degradation enhancer, mannosidase alpha-like protein (EDEM) and translocated to cytosol for proteasomal degradation; a process called ER associated degradation (ERAD) [31]. EDEM1 and EDEM3, in addition to several proteasomal subunits and ubiquitin-related transcripts, were up-regulated upon TTA treatment. Also, proteasome subunit, beta type, 1 (PSMB1), ubiquitin-conjugating enzyme E2B (RAD6 homolog) (UBE2B) and cullin1 (CUL1) were up-regulated (Table 1 and Additional file 1). In addition, TTA also up-regulated sequestosome 1 (SQSTM1), which is able to sequester and shuttle polyubiquitinated, misfolded proteins to the proteasome (reviewed in [54]) (Table 1). Moreover, TTA up-regulated transcripts for parts of the ER translocation machinery which transports proteins to the cytosol, like Sec61 alpha 2 subunit (SEC61A2), Sec61 beta subunit (SEC61B) and SEC63 homolog (SEC63) (Table 1).

\section{TTA affects $\mathrm{Ca}^{2+}$ homeostasis}

Another indication of an ER stress condition in SW620 cells treated with TTA is the altered expression of transcripts coding for proteins involved in $\mathrm{Ca}^{2+}$ homeostasis. The more than 5-fold up-regulation of ATPase, $\mathrm{Ca}^{2}$ ${ }^{+}$-transporting, plasma membrane 4 (ATP2B4/PMCA4) might indicate the presence of a high $\mathrm{Ca}^{2+}$ concentration in the cytosol (Table 1). A possible high $\mathrm{Ca}^{2+}$ level in the cytosol may be part of the ER stress response, with $\mathrm{Ca}^{2+}$ leaking from ER through the up-regulated IP3 receptors, type 1 and 3 (ITPR 1 and 3, Table 1). We also found Phospholipase C D3 (PLCD3), which is known to participate in the generation of IP3 [55], to be up-regulated at mRNA level after TTA-treatment (Table 1).

Among other important $\mathrm{Ca}^{2+}$-related transcripts, we found several $\mathrm{S} 100 \mathrm{Ca}^{2+}$ binding proteins to be differentially expressed after TTA-treatment, e.g. S100P and S100A10 were up-regulated (Table 1 and Additional file 1). Also, TTA caused up-regulation of Stanniocalcin 2 (STC2), which is induced downstream of PERK and critical for survival after UPR [56]. TTA further up-regulated homocysteine-inducible endoplasmic reticulum stress-inducible ubiquitin-like domain member 1 (HERPUD1) (Table 1), which is known to counteract $\mathrm{Ca}^{2+}$ disturbances during ER stress [57].

\section{Effect of TTA on cell cycle}

TTA affected the mRNA level of several cell cycle transcripts, most of them having rather small fold change 


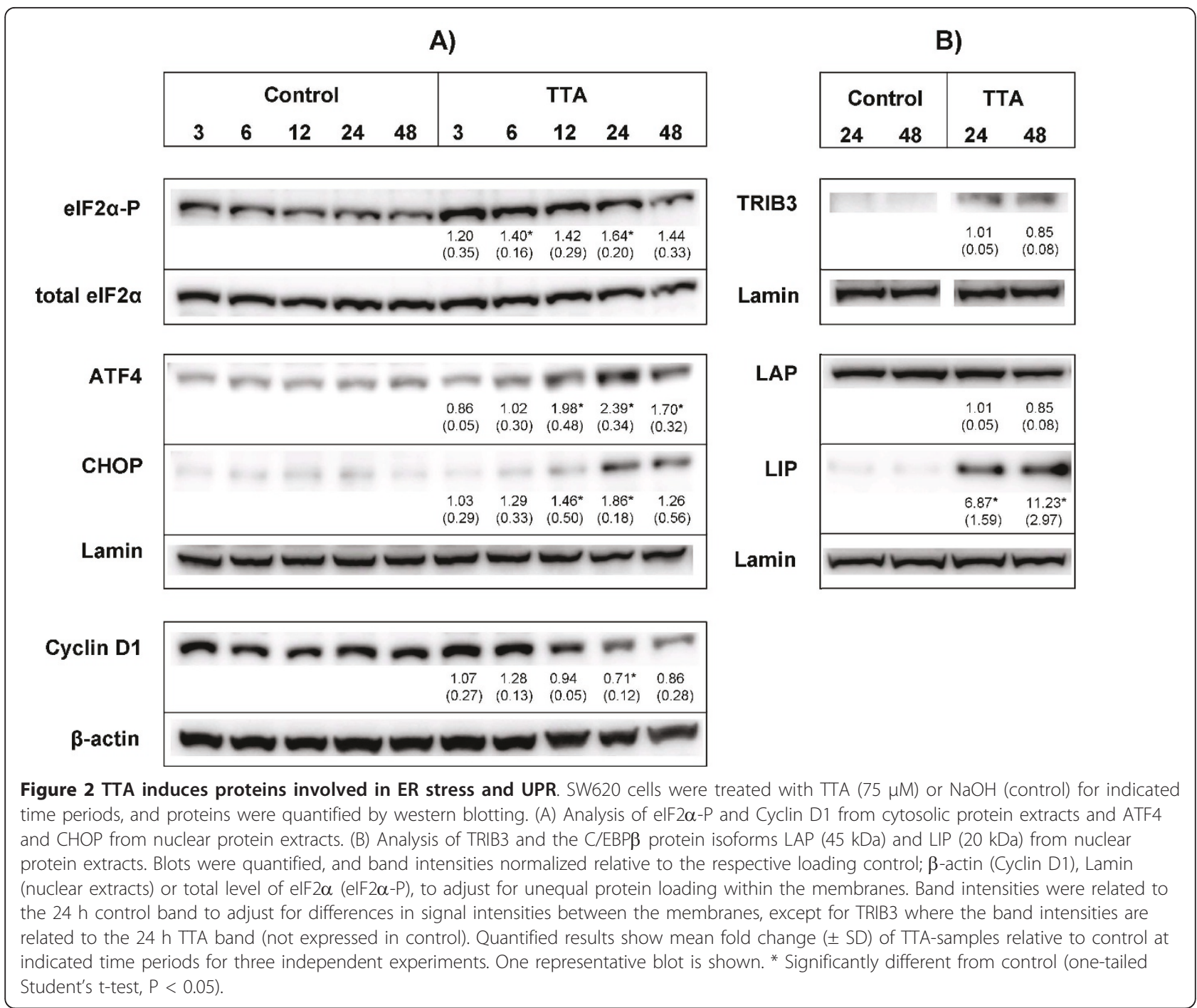

values. Positive cell cycle regulators were down-regulated and negative regulators were up-regulated, as outlined below.

The cell cycle is known to be positively regulated by cyclins (CCNs) and cyclin dependent kinases (CDKs). The mRNA level of cyclin D3 (CCND3), but not cyclin D1, was down-regulated upon TTA treatment (Table 1). However, the protein level of cyclin D1 was significantly decreased after incubation with TTA (Figure 2A). Moreover, transcripts for CCNA2, CCNE1, CCNE2, CCNF, CDK1/CDC2, CDK2, CDK4, CDK5 and CDK6 were down-regulated (Table 1), indicating inhibition of cell cycle progression. The CDK4 inhibitors CDK inhibitor 2A (CDKN2A), CDKN2B and CKDN2D, which are negative regulators of cell cycle, were increased (Table 1). In addition, the tumor suppressor programmed cell death 4 (PDCD4), which is able to reduce the protein level of CDK4 [58], and PDCD6 were up-regulated (Table 1).
Other important cell cycle related transcripts that were up-regulated by TTA were ATF5, stratifin (SFN/ 14-3-3 sigma) and kruppel like factor 4 (KLF4) (Table 1). TTA also induced down-regulation of aurora kinase A (AURKA) and survivin/baculoviral IAP repeat-containing 5 (BIRC5) (Table 1).

\section{TTA changes expression of transcripts involved in ER stress-related apoptosis}

Transcripts related to ER stress-induced apoptosis were also up-regulated upon TTA treatment. In addition to the up-regulation of CHOP and TRIB3, TTA also increased transcription of CASP4, calpain 1, large subunit (CAPN1), CAPN2 and CAPN5 (Table 1).

The C/EBP $\beta$ LIP isoform is known to augment ER stress-induced cell death by interfering with the expression of TRIB3 [59]. C/EBP $\beta$ (CEBPB) was up-regulated 3.2-fold at mRNA level (Table 1) after TTA treatment. 
Western blotting mainly displayed two C/EBP $\beta$ isoforms; a highly expressed $45 \mathrm{kDa}$ LAP isoform and a lower expressed $20 \mathrm{kDa}$ LIP isoform. The $42 \mathrm{kDa}$ LAP* isoform was only found in very low amounts (Figure 2B). TTA did not affect the level of LAP, but induced a significant 6.9- and 11.2-fold induction of LIP after 24 and $48 \mathrm{~h}$, respectively (Figure $2 \mathrm{~B}$ ). The accumulation of LIP at these time points caused a significant 6.6- and 13.3-fold increase in the LIP/LAP ratio after $24 \mathrm{~h}$ and $48 \mathrm{~h}$, respectively, compared to control cells.

During ER stress, cAMP responsive element binding protein 3-like 2 and 3 (CREB3L2 and CREB3L3) are induced in order to attenuate ER stress-induced cell death [60]. These transcripts were also up-regulated (Additional file 1).

\section{Discussion}

Several studies have shown that TTA inhibits the growth of various cancer cells in vitro and in vivo $[13,20,22]$. We have previously shown that TTA inhibits DNA synthesis in SW620 human colon cancer cells in a time- and dose-dependent manner [17], and the growth inhibitory effect of TTA on this cell line was confirmed in the current study by xCELLigence proliferation assay. This assay monitors cell growth real time by measuring changes in electric impedance between two golden electrodes embedded in the bottom of the cell culture wells. The impedance, which is converted to a cell index value, is directly proportional to the number of cells and also reflects the cells' viability, morphology and adhesion strength [61]. The baseline cell index declined compared to the control from approximately 20 hours after TTAsupplementation. Previous studies have indicated that TTA affects multiple biochemical pathways that might play a role in its growth-limiting effect on different cancer cells. However, the exact mechanisms are not yet clear.

This is the first study demonstrating that TTA is able to induce ER stress in cancer cells. Transcripts involved in ER stress and downstream of all three ER stress sensors, like ATF6, IRE1, XBP-1 and ATF4, were found to be differentially expressed after treating SW620 cells with TTA. Also, the increased expression of Hsps and DNAJs indicates that the cells try to increase their protein folding capacity. The up-regulation of EDEM1 and EDEM3, SQSTM1, proteasomal subunits and ubiquitinrelated transcripts indicates activation of ERAD.

The PERK branch of UPR was found to be activated, supported by the increased protein level of eIF $2 \alpha-\mathrm{P}$ and ATF4, as well as up-regulation of several downstream targets of ATF4, like ATF3, ASNS, CHOP and TRIB3, at mRNA level. CHOP and TRIB3, also induced at protein level, are known to link ER stress to ER stressinduced cell death (reviewed in [32]). The enhanced level of these proteins and transcripts for CASP4 and calpains indicates that TTA causes prolonged ER stress and direct the cell fate towards induction of death. We have previously shown that DHA induces ER stress with increased eIF2 $\alpha-\mathrm{P}, \mathrm{ATF} 4$ and CHOP in the same cell line $[28,62]$. We also found HL-60 leukemia cells to induce ER stress upon EPA treatment [63].

In SW620 cells, TTA up-regulated the C/EBP $\beta$ LIP isomer, while LAP was unchanged. LIP is capable of modulating the ER stress response by augmenting cell death, e.g. by enhancing the activity of CHOP [43]. On the contrary, LAP may attenuate ER stress and ER stress induced cell death by inhibiting CHOP [59,64]. However, Li et al. found that LAP modulated the ER stress response by enhancing the expression of pro-apoptotic genes. They also proposed that the ER stress response may be modulated by regulation of the LIP/LAP ratio [42]. We found this ratio to be increased after 24 and $48 \mathrm{~h}$ of TTA treatment, supporting the assumption that TTA causes prolonged ER stress and a switch towards induction of cell death. Even if C/EBP $\beta$ mRNA was upregulated, we only found an increase of LIP at protein level. Different regulation of LIP and LAP might be explained by different synthesis and degradation rates of these isomers [42].

Our results also indicate that TTA affects several transcripts involved in cell cycle progression. Transcripts involved in regulation of both the G1/S and G2/M phases were differentially expressed. In general, positive cell cycle regulators (like CDKs, cyclins, AURKA and survivin) were down-regulated, and negative cell cycle regulators (like ATF5, SFN and KLF4) were up-regulated, which indicates a stop in the cell cycle progression. We have previously demonstrated that DHA treatment of the SW620 cells affects several cell cycle transcripts and proteins like CDKs, cyclins and survivin etc. [62] and arrests the cells in the G2/M phase of the cell cycle [2]. Brewer et. al. stated that cell cycle arrest might be induced during ER stress to prevent cells from completing cell division when the conditions are compromising proper folding and assembly of proteins [65].

TTA also seems to induce changes in expression of transcripts involved in maintenance of $\mathrm{Ca}^{2+}$ homeostasis. The ER lumen contains a high $\mathrm{Ca}^{2+}$ concentration, and induction of ER stress may either come from and/ or culminate with a release of $\mathrm{Ca}^{2+}$ from the ER (reviewed in [66,67]). ER stress-accompanied changes in the $\mathrm{Ca}^{2+}$ metabolism may lead to a pro-apoptotic signal via the mitochondria [66]. We have previously shown that DHA and EPA affect $\mathrm{Ca}^{2+}$ homeostasis in cancer cells $[28,63]$. Apoptosis has been observed in other cancer cells treated with TTA $[13,22]$, and it has been proposed that this effect is mediated via mitochondrial alterations, such as decrease in mitochondrial membrane 
potential and release of Cyt C [13]. CHOP and C/EBP $\beta$ may be involved in the regulation of mitochondrial stress genes like TRIB3 [44] in response to accumulation of unfolded proteins in mitochondria [68]. Their up-regulation by TTA may indicate that the SW620 cells are undergoing a mitochondrial stress after TTA treatment.

Madsen $e t$ al. found TTA to be incorporated mainly into phospholipids in liver after TTA supplementation to rats [69]. The inner mitochondrial membrane phospholipid cardiolipin $(\mathrm{CL})$ is essential for the function of several mitochondrial protein complexes. It interacts with mitochondrial Cyt $\mathrm{C}$, which might utilize reactive oxygen species and cause oxidation of CL. Oxidized CL is required for release of pro-apoptotic factors like Cyt $\mathrm{C}$ to cytosol [70]. Enrichment of EPA and DHA in CL isolated from colonic mucosa in rats fed fish oil or EPA/ DHA ethyl esters might result in high susceptibility to lipid peroxidation due to the FAs' high degree of unsaturation. This may trigger release of pro-apoptotic factors from mitochondria (reviewed in [71]). Decreased synthesis of CL has also been related to Cyt C release from mitochondria during PA-induced apoptosis (reviewed in [9]). It remains to be investigated if this is the case with TTA.

\section{Conclusions}

TTA induces extensive changes in the expression of genes involved in several biological pathways. TTA causes accumulation of misfolded proteins in ER, causing ER stress and activation of UPR. The results show that TTA inhibits SW620 cell growth, at least partly, via the same mechanisms as DHA. Thus, cancer cells seem to cope with stress induced by various FAs through the same mechanisms.

\section{Methods}

\section{Materials and cell culture}

TTA was prepared at the Department of Chemistry, University of Bergen, Norway, as described previously [72] and in Supplementary experimental procedures (Additional file 2). All other solvents were of reagent grade from commercial sources. Antibody specifications are found in Additional file 2. The human colon carcinoma cell line SW620 was obtained from the American Type Culture Collection (ATCC, Rockville, MD) and cultivated in Leibovitz's L-15 medium (Cambrex, BioWhittaker, Walkersville, MD) supplemented with L-glutamine $(2 \mathrm{mM})$, FBS (10\%) and gentamicin (45 mg/l) (complete growth medium), in a humidified atmosphere of $5 \% \mathrm{CO}_{2}: 95 \%$ air at $37^{\circ} \mathrm{C}$.

\section{Cell proliferation assay by $x$ CELLigence}

SW620 cells were seeded in 16 well plates (E-plate 16, Roche, Mannheim, Germany) (12.000 cells in $150 \mu \mathrm{l}$ medium/well), following the xCELLigence Real Time Cell Analyzer (RTCA) DP instrument manual as provided by the manufacturer (Roche). After $\sim 24 \mathrm{~h}$, TTA (75 $\mu \mathrm{M}$, prepared as described in Additional file 2) or the vehicle $\mathrm{NaOH}$ (control medium) was added, and the experiment was allowed to run for $72 \mathrm{~h}$. Average baseline cell index and percent reduction of baseline cell index for TTA-treated cells compared to control cells were calculated for at least two measurements from 4 replicate experiments \pm SD. Significance was calculated using one-tailed Student's t-test $(\mathrm{P}<0.05)$.

\section{RNA isolation, gene expression profiling and statistical analysis}

SW620 cells were seeded in $175 \mathrm{~cm}^{2}$ flasks $\left(3.5 \times 10^{6}\right.$ cells in $28 \mathrm{ml}$ medium). After $24 \mathrm{~h}$ incubation, cells were treated with TTA $(75 \mu \mathrm{M})$ or $\mathrm{NaOH}$ (control) for $24 \mathrm{~h}$. Cell harvesting and total RNA isolation was performed as elaborated in [28], using the High Pure RNA Isolation Kit (Roche). Gene expression profiling was performed following the Eukaryote expression manual from Affymetrix (Santa Clara, CA), using the Human Genome U133 2.0 Plus Array (Affymetrix), as described in Additional file 2. Statistical analysis of gene expression results was performed using the RMA method. Differentially expressed genes were identified using a linear model with a modified T-statistic [73], and results were corrected for multiple testing using the method described in [74] with a false discovery rate of 0.05 . Annotations of probe sets and biological information of genes were retrieved from the web-based NetAffx Analysis Center at affymetrix.com and eGOn at genetools. no. Signal values presented are mean values of 3 replicate experiments. All experiments have been submitted to Array-Express with accession number E-MEXP-2590.

\section{Western blot analysis}

Cells were treated with TTA $(75 \mu \mathrm{M})$ or $\mathrm{NaOH}$ for 3,6 , 12,24 and/or $48 \mathrm{~h}$, as described in the gene expression profiling method. For detection of eIF $2 \alpha-\mathrm{P}$ and cyclin D1, cells were harvested as elaborated in [28], and cytosolic protein extracts were prepared immediately in lysis buffer as described in [63]. Nuclear protein extracts for detection of ATF4, CHOP, TRIB3 and C/EBP $\beta$ were obtained by using Nuclear Extract Kit (Active Motif, Rixensart, Belgium) according to the manufacturer's protocol. Protein concentrations were measured using Bio-Rad Protein Assay (Bio-Rad, Hercules, CA), and the protein extracts were snap-freezed in liquid nitrogen and stored at $-80^{\circ} \mathrm{C}$ until further use. Cytosolic and nuclear proteins ( 80 or $50 \mu \mathrm{g}$ per well, respectively) were separated on $10 \%$ precast denaturing NuPAGE ${ }^{\circledR}$ gels (Invitrogen, Carlsbad, US) and transferred onto Immobilon polyvinylidene difluoride membranes 
(Millipore, Billerica, MA). Membranes were blocked in phosphate buffered saline buffer with $0.1 \%(\mathrm{v} / \mathrm{v})$ Tween $^{\circledR}$ 20 (BioRad, Hercules, CA) and 5\% blocker non-fat dry milk, before incubated with primary and secondary horse radish peroxidase-conjugated antibodies (DAKO, Carpinteria, CA) dissolved in this blocking buffer as described in Additional file 2. eIF2 $\alpha$-P incubations were performed using tris-buffered saline Tween 20 buffer as described in [63]. Blots were detected by chemiluminescense using SuperSignal ${ }^{\circledR}$ West Femto Maximum Sensitivity Substrate (Pierce, Rockford, IL) and visualized by Kodak Image Station 4000R (Eastman Kodak Co., Rochester, NY). Western blot band intensities were quantified using Kodak Molecular Imaging Software (version 4.0.1). Quantified western blot results, based on 3 independent replicates, were analysed as described in the proliferation assay method.

\section{Additional material}

Additional file 1: Supplementary gene expression results. Functional categories of significantly differentially expressed transcripts affected in SW620 cells treated with TTA $(75 \mu \mathrm{M})$ for $24 \mathrm{~h}$, as determined by Affymetrix microarray analysis $(P<0.05)$.

Additional file 2: Supplementary experimental procedures. The file contains supplementing information about the experimental procedures including preparation of TTA stock solution and medium, gene expression experiments and antibodies used.

\section{List of abbreviations}

Transcript short names are to be found in Table 1 and Additional file 1. Cyt C: Cytochrome C; DHA: Docosahexaenoic acid; elF2a: Eukaryote translation initiation factor 2 alpha; EIF2AK3/PERK: elF2a kinase 3; elF2a-P: phoshorylated elF2a; EPA: Eicosapentaenoic acid; ER: Endoplasmic reticulum; ERAD: ER-associated degradation; FAs: Fatty acids; Hsps: Heat shock proteins; LAP: Liver enriched activator protein; LIP: Liver enriched inhibitor protein; $\mathrm{n}$ 3: Omega-3; PA: Palmitic acid; PUFAs: Polyunsaturated fatty acids; TTA: Tetradecylthioacetic acid; UPR: Unfolded protein response

\section{Acknowledgements}

The authors gratefully acknowledge Endre Anderssen, Norwegian Microarray Consortium (NMC), Norwegian University of Science and Technology (NTNU), Trondheim, Norway for microarray statistical analysis. The work was supported by The Faculty of Medicine, NTNU, The Cancer Research Fund, The Research Council of Norway through grants from the Functional Genomics Program (FUGE) and grants from Helse Vest, Norway. Microarray experiments were performed at the microarray core facility at the Norwegian Microarray Consortium (NMC), Trondheim, which is supported by the FUGE, The Norwegian Research Council.

Mailing address for reprints:

Svanhild A. Schonberg, Department of Laboratory Medicine, Children's and Women's Health, Norwegian University of Science and Technology, N-7006, Trondheim, Norway.

\section{Author details}

${ }^{1}$ Norwegian University of Science and Technology, Faculty of Medicine, Department of Laboratory Medicine, Children's and Women's Health, PO Box 8905, N-7491 Trondheim, Norway. ${ }^{2}$ Institute of Medicine, Section of Medical Biochemistry, Haukeland University Hospital, University of Bergen, N-5021 Bergen, Norway.

\section{Authors' contributions}

AGL carried out cell experiments, xCELLigence experiments, western blots and helped to draft the manuscript. CHHP carried out cell experiments, gene expression experiments and drafted the manuscript. KB participated in study design, carried out initial experiments and helped to draft the manuscript. RKB participated in study design. SAS participated in study design and coordination and helped to draft the manuscript. All authors have read and approved the final manuscript.

\section{Competing interests}

The authors declare that they have no competing interests. Rolf $\mathrm{K}$ Berge and Kjetil Berge have stocks in Thia Medica AS. There is no conflict of interest.

Received: 19 September 2011 Accepted: 25 October 2011

Published: 25 October 2011

\section{References}

1. Ferlay J, Autier P, Boniol M, Heanue M, Colombet M, Boyle P: Estimates of the cancer incidence and mortality in Europe in 2006. Ann Oncol 2007, 18(3):581-592.

2. Schonberg $S A$, Lundemo AG, Fladvad T, Holmgren $K$, Bremseth $H$, Nilsen $A$, Gederaas O, Tvedt KE, Egeberg KW, Krokan HE: Closely related colon cancer cell lines display different sensitivity to polyunsaturated fatty acids, accumulate different lipid classes and downregulate sterol regulatory element-binding protein 1. FEBS J 2006, 273(12):2749-2765.

3. Finstad HS, Myhrstad MC, Heimli H, Lomo J, Blomhoff HK, Kolset SO, Drevon CA: Multiplication and death-type of leukemia cell lines exposed to very long-chain polyunsaturated fatty acids. Leukemia 1998, 12(6):921-929.

4. Bathen TF, Holmgren K, Lundemo AG, Hjelstuen MH, Krokan HE, Gribbestad IS, Schonberg SA: Omega-3 fatty acids suppress growth of SW620 human colon cancer xenografts in nude mice. Anticancer Res 2008, 28(6A):3717-3723.

5. Schonberg SA, Rudra PK, Noding R, Skorpen F, Bjerve KS, Krokan HE: Evidence that changes in Se-glutathione peroxidase levels affect the sensitivity of human tumour cell lines to $\mathrm{n}-3$ fatty acids. Carcinogenesis 1997, 18(10):1897-1904.

6. Roynette $\mathrm{CE}$, Calder $\mathrm{PC}$, Dupertuis YM, Pichard C: $\mathrm{n}-3$ polyunsaturated fatty acids and colon cancer prevention. Clin Nutr 2004, 23(2):139-151.

7. Cockbain AJ, Toogood GJ, Hull MA: Omega-3 polyunsaturated fatty acids for the treatment and prevention of colorectal cancer. Gut 2011.

8. Rose DP, Connolly JM: Omega-3 fatty acids as cancer chemopreventive agents. Pharmacol Ther 1999, 83(3):217-244.

9. Tronstad K, Berge K, Berge RK, Bruserud O: Modified fatty acids and their possible therapeutic targets in malignant diseases. Expert Opin Ther Targets 2003, 7(5):663-677.

10. Berge RK, Skorve J, Tronstad K, Berge K, Gudbrandsen OA, Grav H: Metabolic effects of thia fatty acids. Curr Opin Lipidol 2002, 13(3):295-304.

11. Berge K, Tronstad K, Abdi-Dezfuli F, Ranheim T, Mahesparan R, Bjerkvig R, Berge RK: Poorly oxidizable fatty acid analogues inhibit the proliferation of cancer cells in culture. Adv Exp Med Biol 1999, 466:205-210.

12. Tronstad KJ, Berge K, Dyroy E, Madsen L, Berge RK: Growth reduction in glioma cells after treatment with tetradecylthioacetic acid: changes in fatty acid metabolism and oxidative status. Biochem Pharmacol 2001, 61(6):639-649.

13. Tronstad KJ, Gjertsen BT, Krakstad C, Berge K, Brustugun OT, Doskeland SO, Berge RK: Mitochondrial-targeted fatty acid analog induces apoptosis with selective loss of mitochondrial glutathione in promyelocytic leukemia cells. Chem Biol 2003, 10(7):609-618.

14. Iversen PO, Sorensen DR, Tronstad KJ, Gudbrandsen OA, Rustan AC, Berge RK, Drevon CA: A bioactively modified fatty acid improves survival and impairs metastasis in preclinical models of acute leukemia. Clin Cancer Res 2006, 12(11 Pt 1):3525-3531.

15. Tronstad KJ, Bruserud O, Berge K, Berge RK: Antiproliferative effects of a non-beta-oxidizable fatty acid, tetradecylthioacetic acid, in native human acute myelogenous leukemia blast cultures. Leukemia 2002, 16(11):2292-2301.

16. Erikstein BS, McCormack E, Tronstad KJ, Schwede F, Berge R, Gjertsen BT: Protein kinase $A$ activators and the pan-PPAR agonist tetradecylthioacetic acid elicit synergistic anti-leukaemic effects in AML through CREB. Leuk Res 2010, 34(1):77-84 
17. Jensen LR, Berge K, Bathen TF, Wergedahl H, Schonberg SA, Bofin A, Berge RK, Gribbestad IS: Effect of dietary tetradecylthioacetic acid on colon cancer growth studied by dynamic contrast enhanced MRI. Cancer Biol Ther 2007, 6(11):1810-1816.

18. Sorensen HN, Norrheim L, Spydevold O, Gautvik KM: Uptake and receptor binding of dexamethasone in cultured $7800 \mathrm{C} 1$ hepatoma cells in relation to regulation of cell growth and peroxisomal beta-oxidation. Int J Biochem 1990, 22(10):1171-1177.

19. Abdi-Dezfuli F, Berge RK, Rasmussen M, Thorsen T, Aakvaag A: Effects of saturated and polyunsaturated fatty acids and their 3-thia fatty acid analogues on MCF-7 breast cancer cell growth. Ann N Y Acad Sci 1994, 744:306-309.

20. Abdi-Dezfuli F, Froyland L, Thorsen T, Aakvaag A, Berge RK: Eicosapentaenoic acid and sulphur substituted fatty acid analogues inhibit the proliferation of human breast cancer cells in culture. Breast Cancer Res Treat 1997, 45(3):229-239.

21. Pettersen RJ, Salem M, Skorve J, Ulvik RJ, Berge RK, Nordrehaug JE: Pharmacology and safety of tetradecylthioacetic acid (TTA): phase-1 study. J Cardiovasc Pharmacol 2008, 51(4):410-417.

22. Berge K, Tronstad KJ, Flindt EN, Rasmussen TH, Madsen L, Kristiansen K, Berge RK: Tetradecylthioacetic acid inhibits growth of rat glioma cells ex vivo and in vivo via PPAR-dependent and PPAR-independent pathways. Carcinogenesis 2001, 22(11):1747-1755.

23. Skrede S, Sorensen HN, Larsen LN, Steineger HH, Hovik K, Spydevold OS, Horn R, Bremer J: Thia fatty acids, metabolism and metabolic effects. Biochim Biophys Acta 1997, 1344(2):115-131.

24. Berge K, Tronstad KJ, Bohov P, Madsen L, Berge RK: Impact of mitochondrial beta-oxidation in fatty acid-mediated inhibition of glioma cell proliferation. J Lipid Res 2003, 44(1):118-127.

25. Noding R, Schonberg SA, Krokan HE, Bjerve KS: Effects of polyunsaturated fatty acids and their $n-6$ hydroperoxides on growth of five malignant cell lines and the significance of culture media. Lipids 1998, 33(3):285-293.

26. Calviello G, Serini S, Piccioni E, Pessina G: Antineoplastic effects of $n-3$ polyunsaturated fatty acids in combination with drugs and radiotherapy: preventive and therapeutic strategies. Nutr Cancer 2009, 61(3):287-301.

27. Edwards IJ, O'Flaherty JT: Omega-3 Fatty Acids and PPARY in Cancer. PPAR Research 2008, 2008:1-14.

28. Jakobsen $\mathrm{CH}$, Storvold GL, Bremseth H, Follestad T, Sand K, Mack M, Olsen KS, Lundemo AG, Iversen JG, Krokan HE, et al: DHA induces ER stress and growth arrest in human colon cancer cells: associations with cholesterol and calcium homeostasis. J Lipid Res 2008, 49(10):2089-2100.

29. Gu X, Li K, Laybutt DR, He ML, Zhao HL, Chan JC, Xu G: Bip overexpression, but not $\mathrm{CHOP}$ inhibition, attenuates fatty-acid-induced endoplasmic reticulum stress and apoptosis in HepG2 liver cells. Life SCi 2010, 87(23-26):724-732.

30. Wei Y, Wang D, Pagliassotti MJ: Saturated fatty acid-mediated endoplasmic reticulum stress and apoptosis are augmented by trans-10, cis-12-conjugated linoleic acid in liver cells. Mol Cell Biochem 2007, 303(12):105-113.

31. Schroder M, Kaufman RJ: ER stress and the unfolded protein response. Mutat Res 2005, 569(1-2):29-63.

32. Szegezdi E, Logue SE, Gorman AM, Samali A: Mediators of endoplasmic reticulum stress-induced apoptosis. EMBO Rep 2006, 7(9):880-885.

33. Oyadomari S, Mori M: Roles of CHOP/GADD153 in endoplasmic reticulum stress. Cell Death Differ 2004, 11(4):381-389.

34. McCullough KD, Martindale $\lrcorner$, Klotz LO, Aw TY, Holbrook NJ: Gadd153 sensitizes cells to endoplasmic reticulum stress by down-regulating $\mathrm{Bcl} 2$ and perturbing the cellular redox state. Mol Cell Biol 2001, 21(4):1249-1259.

35. Puthalakath H, O'Reilly LA, Gunn P, Lee L, Kelly PN, Huntington ND, Hughes PD, Michalak EM, McKimm-Breschkin J, Motoyama N, et al: ER stress triggers apoptosis by activating BH3-only protein Bim. Cell 2007, 129(7):1337-1349.

36. Chen C, Dudenhausen EE, Pan YX, Zhong C, Kilberg MS: Human CCAAT/ enhancer-binding protein beta gene expression is activated by endoplasmic reticulum stress through an unfolded protein response element downstream of the protein coding sequence. J Biol Chem 2004 279(27):27948-27956

37. Piwien Pilipuk G, Galigniana MD, Schwartz J: Subnuclear localization of C/ EBP beta is regulated by growth hormone and dependent on MAPK. J Biol Chem 2003, 278(37):35668-35677.
38. Smink JJ, Leutz A: Rapamycin and the transcription factor C/EBPbeta as a switch in osteoclast differentiation: implications for lytic bone diseases. $J$ Mol Med 2010, 88(3):227-233.

39. Baldwin BR, Timchenko NA, Zahnow CA: Epidermal growth factor receptor stimulation activates the RNA binding protein CUG-BP1 and increases expression of C/EBPbeta-LIP in mammary epithelial cells. Mol Cell Biol 2004, 24(9):3682-3691.

40. Descombes $P$, Schibler U: A liver-enriched transcriptional activator protein, LAP, and a transcriptional inhibitory protein, LIP, are translated from the same mRNA. Cell 1991, 67(3):569-579.

41. Poli V, Mancini FP, Cortese R: IL-6DBP, a nuclear protein involved in interleukin-6 signal transduction, defines a new family of leucine zipper proteins related to C/EBP. Cell 1990, 63(3):643-653.

42. Li Y, Bevilacqua E, Chiribau CB, Majumder M, Wang C, Croniger CM, Snider MD, Johnson PF, Hatzoglou M: Differential control of the CCAAT/ enhancer-binding protein beta (C/EBPbeta) products liver-enriched transcriptional activating protein (LAP) and liver-enriched transcriptional inhibitory protein (LIP) and the regulation of gene expression during the response to endoplasmic reticulum stress. J Biol Chem 2008, 283(33):22443-22456.

43. Chiribau C-B, Gaccioli F, Huang CC, Yuan CL, Hatzoglou M: Molecular symbiosis of CHOP and C/EBP beta isoform LIP contributes to endoplasmic reticulum stress-induced apoptosis. Mol Cell Biol 2010, 30(14):3722-3731.

44. Ishikawa F, Akimoto T, Yamamoto H, Araki Y, Yoshie T, Mori K, Hayashi H, Nose K, Shibanuma M: Gene expression profiling identifies a role for CHOP during inhibition of the mitochondrial respiratory chain. $J$ Biochem 2009, 146(1):123-132.

45. Ohoka N, Yoshii S, Hattori T, Onozaki K, Hayashi H: TRB3, a novel ER stressinducible gene, is induced via ATF4-CHOP pathway and is involved in cell death. EMBO J 2005, 24(6):1243-1255.

46. Du K, Herzig S, Kulkarni RN, Montminy M: TRB3: a tribbles homolog that inhibits Akt/PKB activation by insulin in liver. Science 2003, 300(5625):1574-1577.

47. Wu M, Xu LG, Zhai Z, Shu HB: SINK is a p65-interacting negative regulator of NF-kappaB-dependent transcription. J Biol Chem 2003, 278(29):27072-27079

48. Hitomi J, Katayama T, Eguchi $Y$, Kudo T, Taniguchi M, Koyama Y, Manabe T, Yamagishi S, Bando Y, Imaizumi K, et al: Involvement of caspase-4 in endoplasmic reticulum stress-induced apoptosis and Abeta-induced cell death. J Cell Biol 2004, 165(3):347-356.

49. Matsuzaki S, Hiratsuka T, Kuwahara R, Katayama T, Tohyama M: Caspase-4 is partially cleaved by calpain via the impairment of $\mathrm{Ca} 2+$ homeostasis under the ER stress. Neurochem Int 2010, 56(2):352-356.

50. Ron D, Walter P: Signal integration in the endoplasmic reticulum unfolded protein response. Nat Rev Mol Cell Biol 2007, 8(7):519-529.

51. Schroder M: Endoplasmic reticulum stress responses. Cell Mol Life SCi 2008, 65(6):862-894.

52. He CH, Gong P, Hu B, Stewart D, Choi ME, Choi AM, Alam J: Identification of activating transcription factor 4 (ATF4) as an Nrf2-interacting protein. Implication for heme oxygenase-1 gene regulation. J Biol Chem 2001, 276(24):20858-20865.

53. Pagani M, Fabbri M, Benedetti C, Fassio A, Pilati S, Bulleid NJ, Cabibbo A, Sitia R: Endoplasmic reticulum oxidoreductin 1-lbeta (ERO1-Lbeta), a human gene induced in the course of the unfolded protein response. J Biol Chem 2000, 275(31):23685-23692.

54. Seibenhener ML, Geetha T, Wooten MW: Sequestosome 1/p62-more than just a scaffold. FEBS Lett 2007, 581(2):175-179.

55. Noh DY, Shin SH, Rhee SG: Phosphoinositide-specific phospholipase C and mitogenic signaling. Biochim Biophys Acta 1995, 1242(2):99-113.

56. Ito D, Walker JR, Thompson CS, Moroz I, Lin W, Veselits ML, Hakim AM, Fienberg AA, Thinakaran G: Characterization of stanniocalcin 2, a novel target of the mammalian unfolded protein response with cytoprotective properties. Mol Cell Biol 2004, 24(21):9456-9469.

57. Chigurupati S, Wei Z, Belal C, Vandermey M, Kyriazis GA, Arumugam TV, Chan SL: The homocysteine-inducible endoplasmic reticulum stress protein counteracts calcium store depletion and induction of CCAAT enhancer-binding protein homologous protein in a neurotoxin model of Parkinson disease. J Biol Chem 2009, 284(27):18323-18333. 
58. Jansen AP, Camalier CE, Colburn NH: Epidermal expression of the translation inhibitor programmed cell death 4 suppresses tumorigenesis. Cancer Res 2005, 65(14):6034-6041.

59. Meir O, Dvash E, Werman A, Rubinstein M: C/EBP-beta regulates endoplasmic reticulum stress-triggered cell death in mouse and human models. PLoS One 2010, 5(3):e9516.

60. Kondo S, Saito A, Hino S, Murakami T, Ogata M, Kanemoto S, Nara S, Yamashita A, Yoshinaga K, Hara H, et al: BBF2H7, a novel transmembrane bZIP transcription factor, is a new type of endoplasmic reticulum stress transducer. Mol Cell Biol 2007, 27(5):1716-1729.

61. Abassi YA, Xi B, Zhang W, Ye P, Kirstein SL, Gaylord MR, Feinstein SC, Wang $X, X u X$ : Kinetic cell-based morphological screening: prediction of mechanism of compound action and off-target effects. Chem Biol 2009, 16(7):712-723.

62. Slagsvold JE, Pettersen $\mathrm{CHH}$, Storvold GL, Follestad T, Krokan HE, Schonberg SA: DHA alters expression of target proteins of cancer therapy in chemoresistant SW620 colon cancer cells. Nutr Cancer 2010, 62(5):611-621.

63. Slagsvold JE, Pettersen CH, Follestad T, Krokan HE, Schonberg SA: The antiproliferative effect of EPA in HL60 cells is mediated by alterations in calcium homeostasis. Lipids 2009, 44(2):103-113.

64. Abreu MM, Sealy L: The C/EBPbeta isoform, liver-inhibitory protein (LIP), induces autophagy in breast cancer cell lines. Exp Cell Res 2010 316(19):3227-3238.

65. Brewer JW, Hendershot LM, Sherr CJ, Diehl JA: Mammalian unfolded protein response inhibits cyclin D1 translation and cell-cycle progression. Proc Natl Acad Sci USA 1999, 96(15):8505-8510.

66. Xu C, Bailly-Maitre B, Reed JC: Endoplasmic reticulum stress: cell life and death decisions. J Clin Invest 2005, 115(10):2656-2664.

67. Verkhratsky A, Toescu EC: Endoplasmic reticulum $\mathrm{Ca}(2+)$ homeostasis and neuronal death. J Cell Mol Med 2003, 7(4):351-361.

68. Zhao Q, Wang J, Levichkin IV, Stasinopoulos S, Ryan MT, Hoogenraad NJ: A mitochondrial specific stress response in mammalian cells. EMBO J 2002, 21(17):4411-4419.

69. Madsen L, Froyland L, Grav HJ, Berge RK: Up-regulated delta 9-desaturase gene expression by hypolipidemic peroxisome-proliferating fatty acids results in increased oleic acid content in liver and VLDL: accumulation of a delta 9-desaturated metabolite of tetradecylthioacetic acid. J Lipid Res 1997, 38(3):554-563.

70. Bayir H, Fadeel B, Palladino MJ, Witasp E, Kurnikov IV, Tyurina YY, Tyurin VA, Amoscato AA, Jiang J, Kochanek PM, et al: Apoptotic interactions of cytochrome c: redox flirting with anionic phospholipids within and outside of mitochondria. Biochim Biophys Acta 2006, 1757(5-6):648-659.

71. Chapkin RS, Seo J, McMurray DN, Lupton JR: Mechanisms by which docosahexaenoic acid and related fatty acids reduce colon cancer risk and inflammatory disorders of the intestine. Chem Phys Lipids 2008, 153(1):14-23.

72. Spydevold O, Bremer J: Induction of peroxisomal beta-oxidation in 7800 C1 Morris hepatoma cells in steady state by fatty acids and fatty acid analogues. Biochim Biophys Acta 1989, 1003(1):72-79.

73. Smyth GK: Linear models and empirical bayes methods for assessing differential expression in microarray experiments. Stat Appl Genet Mol Biol 2004, 3:Article 3.

74. Benjamini $Y$, Hochberg $Y$ : Controlling the false discovery rate: a practical and powerful approach to muliple testing. J R Stat Soc 1995, 57(1):289-300[http://www.ncbi.nlm.nih.gov/pubmed/16740248].

doi:10.1186/1476-511X-10-190

Cite this article as: Lundemo et al: Tetradecylthioacetic acid inhibits proliferation of human SW620 colon cancer cells - gene expression profiling implies endoplasmic reticulum stress. Lipids in Health and Disease 2011 10:190.

\section{Submit your next manuscript to BioMed Central and take full advantage of:}

- Convenient online submission

- Thorough peer review

- No space constraints or color figure charges

- Immediate publication on acceptance

- Inclusion in PubMed, CAS, Scopus and Google Scholar

- Research which is freely available for redistribution

Submit your manuscript at www.biomedcentral.com/submit
Biomed Central 